\title{
Review Article \\ Pomegranate Fruit as a Rich Source of Biologically Active Compounds
}

\author{
Sreeja Sreekumar, Hima Sithul, Parvathy Muraleedharan, \\ Juberiya Mohammed Azeez, and Sreeja Sreeharshan \\ Cancer Research Program, Rajiv Gandhi Centre for Biotechnology, Thycaud P.O, Thiruvananthapuram, Kerala 695014 , India \\ Correspondence should be addressed to Sreeja Sreeharshan; sreejasreeharshan@yahoo.com
}

Received 21 November 2013; Revised 25 February 2014; Accepted 25 February 2014; Published 10 April 2014

Academic Editor: Kota V. Ramana

Copyright (c) 2014 Sreeja Sreekumar et al. This is an open access article distributed under the Creative Commons Attribution License, which permits unrestricted use, distribution, and reproduction in any medium, provided the original work is properly cited.

Pomegranate is a widely used plant having medicinal properties. In this review, we have mainly focused on the already published data from our laboratory pertaining to the effect of methanol extract of pericarp of pomegranate (PME) and have compared it with other relevant literatures on Punica. Earlier, we had shown its antiproliferative effect using human breast (MCF-7, MDA MB-231), and endometrial (HEC-1A), cervical (SiHa, HeLa), and ovarian (SKOV3) cancer cell lines, and normal breast fibroblasts (MCF-10A) at concentration of $20-320 \mu \mathrm{g} / \mathrm{mL}$. The expressions of selected estrogen responsive genes (PR, pS2, and C-Myc) were downregulated by PME. Unlike estradiol, PME did not increase the uterine weight and proliferation in bilaterally ovariectomized Swiss-Albino mice models and its cardioprotective effects were comparable to that of $17 \beta$-estradiol. We had further assessed the protective role of PME on skeletal system, using MC3T3-E1 cells. The results indicated that PME $(80 \mu \mathrm{g} / \mathrm{mL})$ significantly increased ALP (Alkaline Phosphatase) activity, supporting its suggested role in modulating osteoblastic cell differentiation. The antiosteoporotic potential of PME was also evaluated in ovariectomized (OVX) rodent model. The results from our studies and from various other studies support the fact that pomegranate fruit is indeed a source of biologically active compounds.

\section{Introduction}

Punica granatum L. (Punicaceae) is a nutrient dense fruit rich in phytochemical compounds [1]. Plants produce low molecular weight compounds which are broadly called phytochemicals, usually as a mechanism of defence. Some plants contain distinct families of phytocompounds, which are structurally similar to steroid hormone, $17 \beta$-estradiol (E2) and compete with the endogenous hormone for binding to estrogen receptor (ER), thus reducing the hormonal effect of endogenous estrogens [2-4]. These compounds are termed as phytoestrogens. Most of these phytoestrogens present in the diet are inactive compounds, which, on consumption, go through series of enzymatic changes in the gastrointestinal tract, resulting in the formation of compounds having structure similar to that of estrogens [5]. Phytoestrogens have captured major research and clinical attention due to its effectiveness in the prevention and treatment of perimenopausal and menopausal symptoms, over hormone replacement therapy (HRT) [6]. They may act both as agonists and/or antagonists in a site-specific manner, similar to the hormonal action of selective estrogen receptor modulators (SERMs) [7-9]. It can also function as antioxidants and protect DNA from oxidant-induced damage [10]. Research on pomegranate is gaining momentum due to its tremendous nutritional values and medicinal uses. The current review focuses on the use of pomegranate as a phytoestrogen rich and nutraceutical fruit with emphasis to the work done in our laboratory using methanolic extract of pericarp of pomegranate (PME).

\section{Chemical Constituents of Pomegranate Fruit and Tree}

The chemical composition of the fruits differs depending on the cultivar, growing region, maturity, cultivation practice, 
TABLE 1: Principal constituents of different parts of pomegranate tree and fruit. The different parts of pomegranate plant like peel, root, bark, flower, leaves, and so forth exhibit different phytochemicals.

\begin{tabular}{|c|c|c|c|c|c|}
\hline Pomegranate peel & Pomegranate juice & $\begin{array}{l}\text { Pomegranate root } \\
\text { and bark }\end{array}$ & $\begin{array}{l}\text { Pomegranate } \\
\text { flower }\end{array}$ & Pomegranate leaves & Pomegranate seed \\
\hline $\begin{array}{l}\text { (i) Gallic acid } \\
\text { (ii) Ellagic acid } \\
\text { (iii) Punicalin } \\
\text { (iv) Punicalagin } \\
\text { (v) Caffeic acid } \\
\text { (vi) Ellagitannins } \\
\text { (vii) Pelletierine } \\
\text { alkaloids } \\
\text { (viii) Luteolin } \\
\text { (ix) Kaempferol } \\
\text { (x) Quercetin }\end{array}$ & $\begin{array}{l}\text { (i) Simple sugars } \\
\text { (ii) Aliphatic organic } \\
\text { acids } \\
\text { (iii) Gallic acid } \\
\text { (iv) Ellagic acid } \\
\text { (v) Quinic acid } \\
\text { (vi) Flavonols } \\
\text { (vii) Amino acids } \\
\text { (viii) Minerals } \\
\text { (ix) EGCG } \\
\text { (x) Ascorbic acid }\end{array}$ & $\begin{array}{l}\text { (i) Ellagitannins } \\
\text { (ii) Piperidine } \\
\text { alkaloids } \\
\text { (iii) Pyrrolidine } \\
\text { alkaloid } \\
\text { (iv) Pelletierine } \\
\text { alkaloids }\end{array}$ & $\begin{array}{l}\text { (i) Gallic acids } \\
\text { (ii) Ursolic acid } \\
\text { (iii) Triterpenoids } \\
\text { (iv) Fatty acids }\end{array}$ & $\begin{array}{l}\text { (i) Carbohydrates } \\
\text { (ii) Reducing sugars } \\
\text { (iii) Sterols } \\
\text { (iv) Saponins } \\
\text { (v) Flavanoids } \\
\text { (vi) Tannins } \\
\text { (vii) Piperidine } \\
\text { alkaloids } \\
\text { (viii) Flavone } \\
\text { (ix) Glycoside } \\
\text { (x) Ellagitannins }\end{array}$ & $\begin{array}{l}\text { (i) } 3,3^{\prime} \text {-Di-O-methylellagic } \\
\text { acid } \\
\text { (ii) } \\
3,3^{\prime}, 4^{\prime} \text {-Tri-O-methylellagic } \\
\text { acid } \\
\text { (iii) Punicic acid } \\
\text { (iv) Oleic acid } \\
\text { (v) Palmitic acid } \\
\text { (vi) Stearic acid } \\
\text { (vii) Linoleic acid } \\
\text { (viii) Sterols } \\
\text { (ix) Tocopherols } \\
\text { (x) Sex steroids }\end{array}$ \\
\hline References [20-26] & $\begin{array}{l}\text { References } \\
{[15,20,26-30]}\end{array}$ & References $[21,23]$ & References [31-33] & $\begin{array}{l}\text { References } \\
{[21,22,34,35]}\end{array}$ & References [36-41] \\
\hline
\end{tabular}

climate, and storage circumstances [11]. About 50\% of the total fruit weight corresponds to the peel, which is an important source of bioactive compounds such as phenolics, flavonoids, ellagitannins, and proanthocyanidin compounds, minerals, mainly potassium, nitrogen, calcium, phosphorus, magnesium, and sodium, and complex polysaccharides. The edible part of the pomegranate fruit (50\%) consists of $40 \%$ arils and $10 \%$ seeds. Arils contain $85 \%$ water, $10 \%$ total sugars, mainly fructose and glucose, and $1.5 \%$ pectin, organic acid, such as ascorbic acid, citric acid, and malic acid, and bioactive compounds such as phenolics and flavonoids, principally anthocyanins [12]. The seed cover of the fruit contains delphinidin-3-glucoside, cyanidin-3-glucoside, delphinidin3,5-diglucoside, cyanidin-3,5-diglucoside, pelargonidin-3,5diglucoside, and pelargonidin-3-glucoside with delphinidin3,5-diglucoside being the main anthocyanin in pomegranate juice [13]. 12-20\% of total seed weight of pomegranate comprises seed oil and is self-possessed with more than $70 \%$ of the conjugated linolenic acids. The fatty acid component of pomegranate seed oil comprises over $95 \%$ of the oil, of which $99 \%$ is triacylglycerols. Minor components of the oil include sterols, steroids, and a key component of mammalian myelin sheaths, cerebroside [14, 15]. Interestingly, punicic acid, which is a conjugated isomer unique to pomegranate oil, constitutes $70-76 \%$ of the seed oil [16]. Phenolic compounds, together with flavonoids, anthocyanins, and tannins, are the main group of antioxidant phytochemicals that are important due to their biological and free radical scavenging activities [17]. Phenolic acids, flavonoids, and tannins are present in different parts of pomegranate fruit and this may be one of the reasons why many of the studies demonstrated that combinations of pomegranate extracts from different parts of the fruit were more effective than a single extract [18]. In a comparative analysis, anthocyanins from pomegranate fruit were found to possess higher antioxidant activity than vitamin-E ( $\alpha$-tocopherol), $\beta$-carotene, and ascorbic acid [19]. Table 1 represents the key constituents of pomegranate fruit and tree [20-41].

\section{Therapeutic Functions of Pomegranate}

Extracts of all parts of the pomegranate fruit exhibit therapeutic properties [15] and target a range of diseases including cancer, cardiovascular disorders, diabetes, male infertility, Alzheimer's disease [42], aging, and AIDS [43] (Figure 1). Although pomegranate's extensive therapeutic benefits may be attributed to a number of mechanisms, most researchers have determined its antioxidant, anticarcinogenic, and antiinflammatory properties. Various therapeutic applications of Punica granatum are discussed here.

3.1. Cancer. Research on breast cancer cell lines demonstrated that pomegranate constituents efficiently inhibited angiogenesis [44], invasiveness [40], growth [45], and induced apoptosis [46]. Its anti-invasive, antiproliferative, and antimetastatic effects were attributed to the modulation of Bcl-2 proteins, upregulation of p27 and p21, and downregulation of cyclin-cdk network [47]. Pomegranate constituents inhibit angiogenesis via downregulation of vascular endothelial growth factor (VEGF) in human umbilical vein endothelial and MCF-7 breast cancer cell lines [44], thereby hampering the tumor growth. Prostate cancer cells, when treated with pomegranate juice, increased adhesion and decreased the migration. Molecular analyses revealed that pomegranate juice increased the expression of celladhesion related genes and inhibited the expression of genes involved in cytoskeletal function and cellular migration. It would possibly affect prostate cancer because of its apoptotic, antioxidant, antiproliferative, and anti-inflammatory properties, suggesting that it may be beneficial in slowing down or preventing cancer cell metastasis [48]. The application of pomegranate extract to the skin of mice before they were exposed to a carcinogenic agent was shown to inhibit the appearance of erythemas and hyperplasia and the activity of epithelial ornithine decarboxylase [49]. An in vivo study in TRAMP mice model suggested that oral supplementation of 


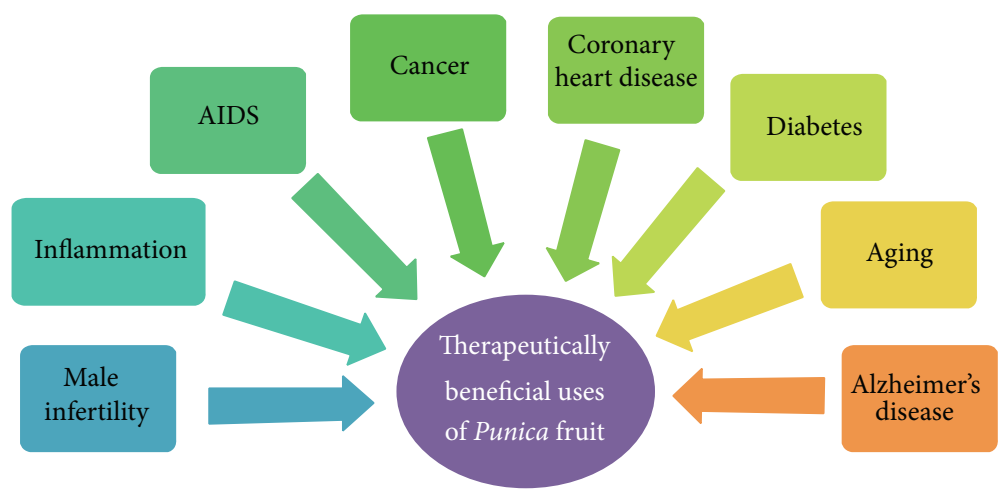

Figure 1: Therapeutically beneficial uses of Punica fruit. Pomegranate fruit has been proven to act against various diseases like cancer, cardiovascular disorders, diabetes, AIDS, and Alzheimer's disease.

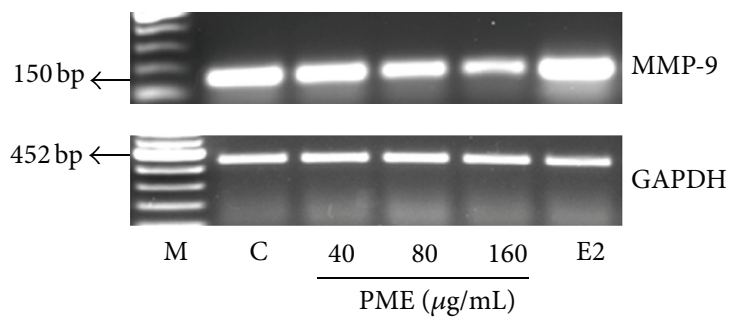

(a)

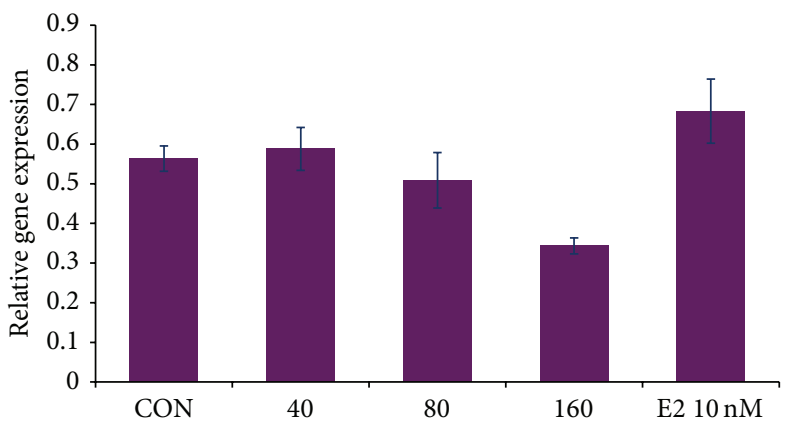

(b)

FIGURE 2: Effect of PME on MMP-9 transcription in MCF7 cells. (a) MCF7 cells were incubated with PME (40, 80, and 160 $\mu \mathrm{g} / \mathrm{mL})$ and E2 $(10 \mathrm{nM})$ for $24 \mathrm{hrs}$ and semiquantitative RT-PCR was done. (b) shows the ratio of density of MMP-9 gene expression to that of endogenous control GAPDH and it represents mean \pm SE of 3 replicates $\left({ }^{*} P<0.05\right)$.

pomegranate fruit extract inhibited metastasis and increased overall survival [50].

Matrix metalloproteinases (MMPs) are good markers of tumor cell invasion and migration [51]. Phytochemicals have been shown to target the activity and secretion of MMPs in estrogen responsive cancers [52]. Constituents of pomegranate minimize tumor cell invasion into normal tissue and metastasis to distant sites and these actions develop due to the inhibition of selected metalloproteinase activity, decreased focal adhesion kinase activity, and reduced VEGF expression [15]. With semiquantitative RT-PCR, we had found out that PME downregulated the transcription of MMP-9 suggesting its possible role in the inhibition of tumor invasion (Figure 2) whereas E2 $(10 \mathrm{nM})$ did not significantly affect the transcription of MMP-9 [53] which correlated with earlier studies suggesting that estrogen stimulated MMP-9 secretion without increasing its gene transcription [54].

We had assessed the estrogenicity/antiestrogenicity of $\mathrm{PME}$ in a panel of in vitro biological assays and the expression of endogenous estrogen sensitive markers (pS2 and PR) in breast carcinoma cell lines were analyzed [53]. When MCF-7 cells pretreated with PME were treated with estrogen, the c-Myc expression was not induced as much as when treated with estrogen alone, demonstrating the effect of PME in estrogen regulated mechanism (Figure 3 ). ER positive cells treated with PPT $\left(4,4^{\prime}, 4^{\prime \prime}-(4\right.$-Propyl- $(1 H)$ pyrazole-1,3,5-triyl)trisphenol) (ER $\alpha$ selective agonist) and DPN (Diarylpropionitrile) (ER $\beta$ selective agonist) clearly showed that PPT increased the pS2 protein levels, whereas DPN did not produce any significant effect. When given in 


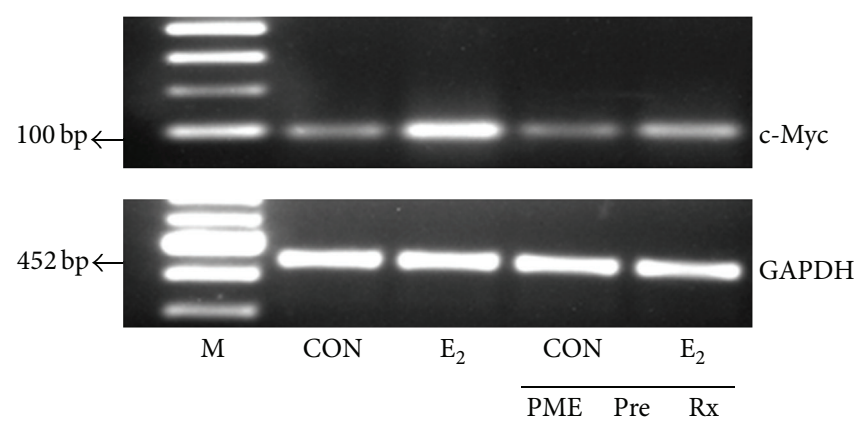

(a)

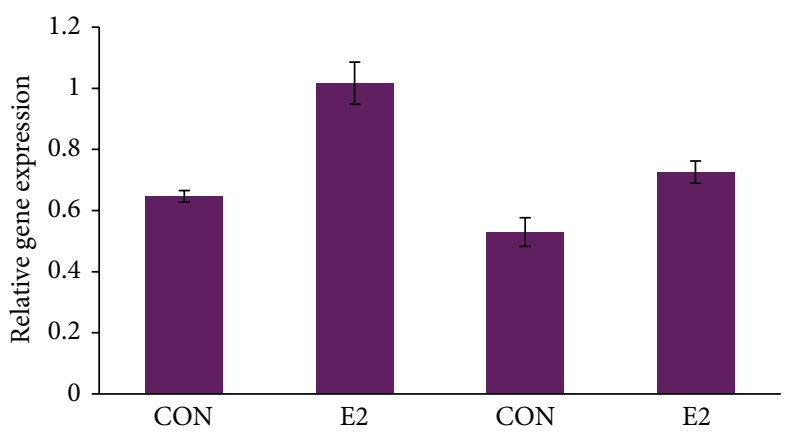

(b)

Figure 3: Effect of PME pretreatment on E2 induced expression of c-Myc. (a) MCF7 cells were pretreated with $100 \mathrm{nM}$ E2 for 4 hrs, with or without PME pretreatment $(80 \mu \mathrm{g} / \mathrm{mL})$ for $12 \mathrm{hrs}$ and RT-PCR was done. (b) shows the ratio of density of c-Myc gene expression to that of endogenous control GAPDH and it represents mean \pm SE of 3 replicates $\left({ }^{*} P<0.05\right)$.

combination with PPT, PME reduced the pS2 protein levels indicating the role of $\mathrm{ER} \alpha$ in mediating the effects of PME on pS2 expression (Figure 4). Thus the effect of PME on expression of $\mathrm{pS} 2$ was mediated by $\mathrm{ER} \alpha$ and not by $\mathrm{ER} \beta$ [53].

Pomegranate fruit extract was revealed to inhibit UVB-mediated phosphorylation of mitogen-activated protein kinase (MAPK) and nuclear factor NF- $\kappa \mathrm{B}$ activation [55]. Pomegranate juice almost downregulated the $\mathrm{TNF} \alpha$ induced Akt (protein kinase B) activation required for $\mathrm{NF}-\kappa \mathrm{B}$ activity [56]. Koyama et al. [57] examined the effects of pomegranate extract (POMx) on the IGF system and found out cell growth inhibition and apoptosis. Their findings suggested that POMx treatment reduced mTOR phosphorylation at Ser2448 and Ser2481, whereas IGFBP-3 increased phosphorylation at those sites. These results suggested that POMx decreased prostate cancer cell survival by inhibiting IGF1 expression. To conclude, pomegranate fruit has anticancer properties that can be attributed to different mechanisms.

3.2. Cardiovascular Disorders. In vitro, in vivo and human trials had examined the effects of a range of pomegranate constituents on the prevention and reduction of atherosclerosis and LDL oxidation [58]. Evidence suggested that polyphenolic antioxidants contained in pomegranate juice can cause reduction of oxidative stress and atherogenesis through the activation of redox-sensitive genes ELK-1 and p-JUN and increased eNOS expression. Their results indicated that proatherogenic effects induced by disturbed shear stress can be reversed by constant administration of pomegranate juice [59]. Pomegranate juice consumption for 3 years by patients with carotid artery stenosis reduced common blood pressure, LDL oxidation, and carotid intima-media thickness [60]. Azadzoi et al. demonstrated that 8-week administration of pomegranate juice concentrate daily in a rabbit model of arteriogenic erectile dysfunction significantly increased intracavernous blood flow and smooth muscle relaxation, probably via its antioxidant effect on enhanced nitric oxide preservation and bioavailability [61]. A pilot study in type 2 diabetic patients with hyperlipidemia found that concentrated pomegranate juice decreased cholesterol absorption, increased faecal excretion of cholesterol, had a favourable effect on enzymes concerned in cholesterol metabolism, drastically reduced LDL cholesterol, and improved LDL/HDL cholesterol and total/HDL ratios [62]. Aviram et al. analyzed atherosclerotic lesion size, antioxidant activity, blood sugar, peritoneal macrophages, oxidative status, and lipid profiles for 3 months after giving 6 different pomegranate preparations with varying amounts of total polyphenols and gallic acid content in atherosclerotic apolipoproteinE deficient mice and found that pomegranate phenolics and pomegranate unique complexed sugars could mimic the antiatherogenic effects of pomegranate extracts [63]. All these evidences suggest the potential cardioprotective effect of pomegranate fruit. 


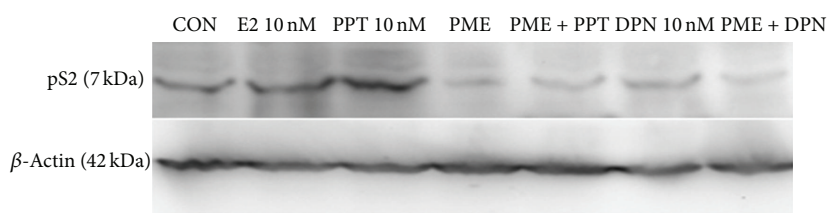

(a)

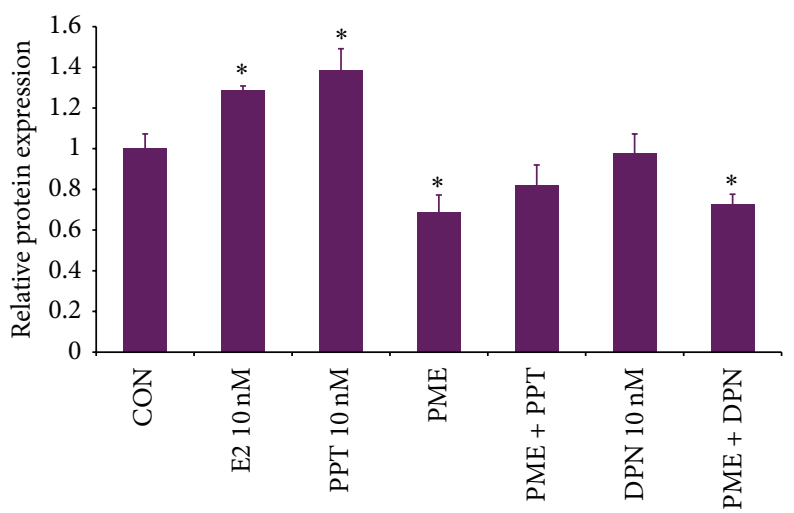

(b)

FIGURE 4: Effect of PME on pS2 protein expression in MCF7 cells. (a) Immunoblot result of MCF7 cells treated with $10 \mathrm{nM}$ E2, PME $(80 \mu \mathrm{g} / \mathrm{mL}), 10 \mathrm{nM}$ PPT, $10 \mathrm{nM}$ DPN, and PME $(80 \mu \mathrm{g} / \mathrm{mL})$ with $10 \mathrm{nM}$ PPT or $10 \mathrm{nM} \mathrm{DPN}$ for $48 \mathrm{hrs}$. (b) Data are presented as densitometric ratio relative to nontreated control $(\mathrm{CON})$ cells. The values are mean \pm SE of 3 separate experiments $\left({ }^{*} P<0.05\right)$.

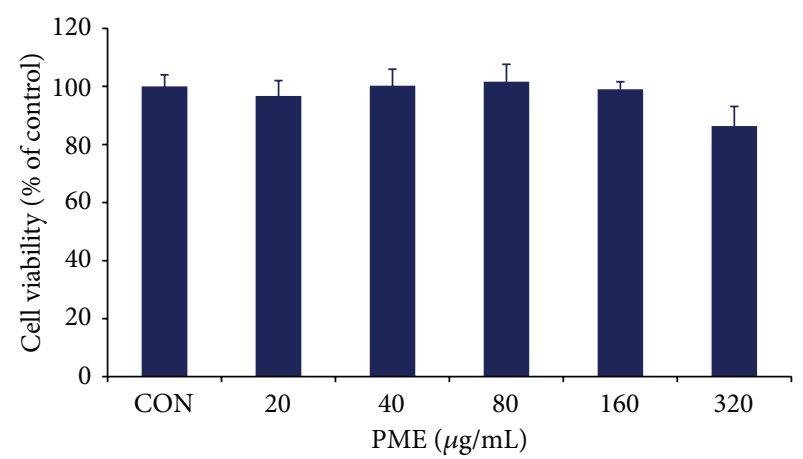

(a)

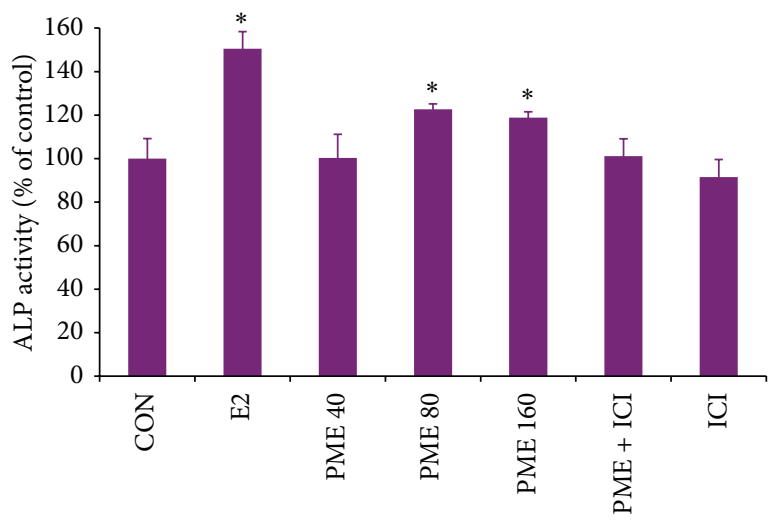

(b)

FIGURE 5: PME increased ALP activity in MC3T3-E1 osteoblast without affecting cell proliferation. (a) Dose-dependent effect of PME on cell proliferation. MC3T3-E1 osteoblasts were treated with 0 (control), 20, 40, 80, 160, and $320 \mu \mathrm{g} / \mathrm{mL}$ of PME for 48 hrs and the cell proliferation was determined by MTT assay. The cell proliferation was expressed as percentage cell viability over the untreated control. (b) Cells were treated with E2 $(10 \mathrm{nM}), \operatorname{PME}(40,80$, and $160 \mu \mathrm{g} / \mathrm{mL})$, ICI $(1 \mu \mathrm{M})$ with or without PME $(80 \mu \mathrm{g} / \mathrm{mL})$ for $48 \mathrm{hrs}$. ALP activity was then measured and results are expressed as percentage over the untreated control. Results are expressed as mean values \pm SE of five replicates. ${ }^{*} P<0.05$ when compared to untreated control.

3.3. Antiosteoporotic Potential. Tissue selective estrogen agonist/antagonists are currently being investigated as alternatives to estrogen in the prevention and treatment of postmenopausal osteoporosis [64-66]. Bone loss after ovariectomy is associated with high bone turnover where bone resorption rate exceeds the bone formation rate [67]. To assess the protective role of Punica on skeletal system, we had examined the effect of PME on a well-characterized osteoblastic cell population (osteoblastic MC3T3-E1 cells) and examined its effect on Alkaline Phosphatase (ALP), which is a commonly used bone remodelling marker. The results (Figure 5) indicated that PME significantly increased ALP activity, supporting its suggested role in modulating osteoblastic cell differentiation [68].

Ovariectomized rodent model is a well-established system for estrogen deficiency induced bone loss and used by researchers previously $[69,70]$. We had evaluated the antiosteoporotic potential of the extract in estrogen deficiency induced osteoporosis in young adult mice of 6-8 weeks of age by assessing the bone turnover by serum ALP. In 
TABLE 2: Effect of E2, PME, and tamoxifen on chosen markers of bone metabolism of ovariectomized mice. Serum calcium, phosphorus, and Alkaline Phosphatase (ALP) levels of sham control (SS Con) and Ovx mice exposed to $0.1 \%$ ethanol (vehicle control), E2 (1 mg/kg bwt), PME $(50,100 \mathrm{mg} / \mathrm{kg}$ bwt), and tamoxifen (TAM, $10 \mathrm{mg} / \mathrm{kg}$ bwt) for 7 days (bwt = body weight). Data are expressed as mean $\pm \mathrm{SE}(n=5)$.

\begin{tabular}{lcccccc}
\hline & Sham control & OVX control & $\begin{array}{c}\text { E2 } \\
(1 \mathrm{mg} / \mathrm{kg} \mathrm{bwt})\end{array}$ & $\begin{array}{c}\text { PME } \\
(50 \mathrm{mg} / \mathrm{kg} \mathrm{bwt})\end{array}$ & $\begin{array}{c}\text { PME } \\
(100 \mathrm{mg} / \mathrm{kg} \mathrm{bwt})\end{array}$ & $\begin{array}{c}\text { TAM } \\
(10 \mathrm{mg} / \mathrm{kg} \mathrm{bwt})\end{array}$ \\
\hline Calcium (mg/dL) & $9.46 \pm 0.313$ & $10.94 \pm 1.18$ & $8.188 \pm 0.7040^{\mathrm{a}}$ & $8.5 \pm 0.707$ & $9.09 \pm 0.194$ & $9.908 \pm 0.165$ \\
Phosphorus (mg/dL) & $7.43 \pm 0.63$ & $8.818 \pm 0.698$ & $8.026 \pm 1.066$ & $7.516 \pm 1.731$ & $8.78 \pm 1.980$ & $8.146 \pm 0.0680$ \\
ALP (U/L) & $140.6 \pm 11.28$ & $181.8 \pm 34.07^{\mathrm{a}}$ & $115.2 \pm 23.61^{\mathrm{b}}$ & $130.4 \pm 12.77$ & $120 \pm 9.02^{\mathrm{b}}$ & $134.6 \pm 17.54^{\mathrm{b}}$ \\
\hline
\end{tabular}

${ }^{\mathrm{a}} P<0.05$ versus sham control, ${ }^{\mathrm{b}} P<0.05$ versus ovx control.

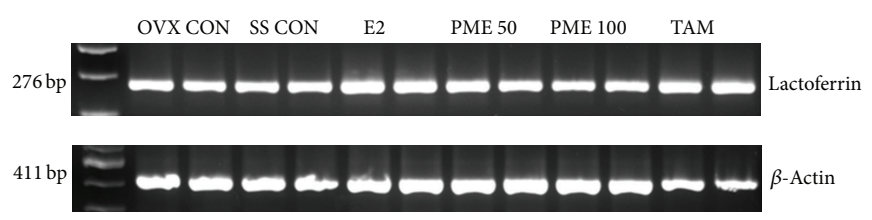

(a)

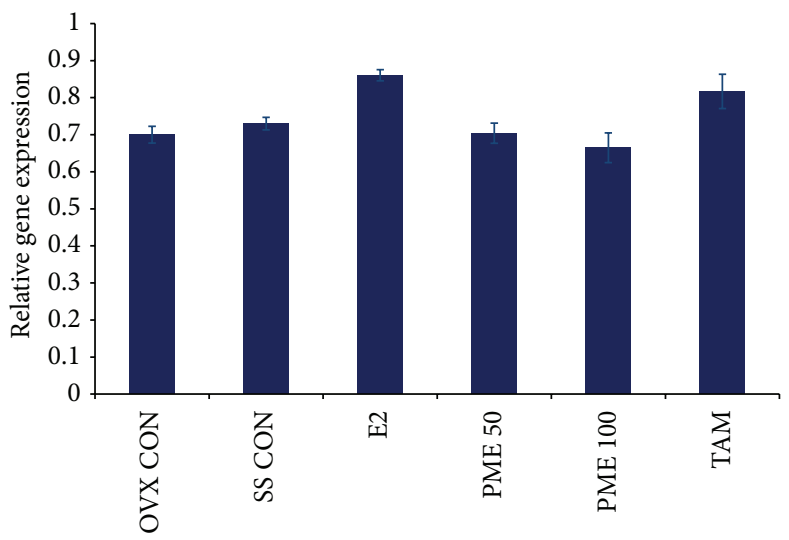

(b)

FIGURE 6: PME did not alter lactoferrin expression in murine uterus. (a) RT-PCR detection of Lactoferrin m-RNA in sham control (SS CON) and ovariectomized mice exposed to $0.1 \%$ ethanol (vehicle control, Ovx CON), E2 (1 mg/kg bwt), PME (50, $100 \mathrm{mg} / \mathrm{kg}$ bwt), and tamoxifen (TAM, $10 \mathrm{mg} / \mathrm{kg}$ bwt) for 7 days. (b) shows the ratio of density of target gene expression to that of endogenous control beta-actin and it represents mean \pm SE of three replicates.

comparison to the sham surgery (SS) control, ovariectomized (Ovx) control animals showed an increase in ALP activity indicating an increase in bone turn-over rate in these animals. PME in higher concentration was found to be effective in decreasing this bone turnover, though $\mathrm{E} 2$ was better in controlling the accelerated bone turnover (Table 2). The experimental model differed from aged Ovx mice wherein the osteoporosis is induced only by estrogen deficiency and not by a combination of natural bone loss due to age and ovarian hormone deficiency. An increase in bone turn-over rate was indicated by higher serum ALP level in the Ovx group compared to the SS control group. Therefore, high rate of bone turnover was well corrected by PME suggesting that it might play a protective role against ovarian hormone insufficiency related bone resorption. But E2 as well as PME was able to significantly decrease ALP levels in Ovx mice (Table 2). Serum calcium and phosphorous levels in Ovx control, PME treated, and tamoxifen treated animals were similar to that of SS control animals. Significant decrease in calcium levels was observed in E2 treated animals in comparison to SS control (Table 2). Our findings clearly in- dicated that the possible bone preserving effect of PME is almost comparable with E2 [53]. Earlier studies had shown that an acute or chronic exposure to xenoestrogens or dietary phytoestrogens alters uterine expression of estrogen sensitive genes in mice [71]. So in order to check whether PME has any effect, a semiquantitative RT-PCR was done to analyze uterine mRNA levels of lactoferrin in ovariectomized mice fed with PME for 7 days. Lactoferrin is a well-known estrogen target gene and a biologically active molecule for bone regeneration [72]. The positive control E2 increased the uterine accumulation of lactoferrin mRNA in Ovx animals compared to the vehicle treated Ovx control (Figure 6). Lactoferrin expression did not differ significantly between the groups that received PME $(50,100 \mathrm{mg} / \mathrm{kg}$ bwt $)$ and the vehicle $(0.1 \%$ ethanol) treated Ovx control group, indicating the lack of estrogenicity of PME on uterine endometrium in the doses tested in our study. Tamoxifen $(10 \mathrm{mg} / \mathrm{kg}$ bwt $)$ was found to increase the 
expression of lactoferrin, though not significantly [68]. As there are promising results from both in vitro and in vivo studies, we suggest evaluating the antiosteoporotic potential by clinical trials with pomegranate fruit extract that has no side effects on uterine endometrium alongside a significant decrease in bone turn-over rate.

3.4. Other Clinical Applications. In vitro assay showed that fermented pomegranate juice extract is better than red wine and comparable to green tea [37]. There were also reports that pomegranate juice possessed considerably greater antioxidant capacity at much lower concentrations (>1000-fold dilutions) than either grape or blueberry juice [73]. Punica granatum peel extract decreased lipid peroxidation in hepatic, cardiac, and renal tissues and at the same time it had a facilitatory effect on the scavenging capability of superoxide anion and hydrogen peroxide [74]. Formerly, it was shown that pomegranate peel extract supplementation alleviated oxidative damage of the liver and enhanced the hepatic structure and function in rats exposed to bile duct ligation [75]. Pretreatment of carbon tetrachloride-induced liver damage in rats with pomegranate peel extract resulted in the reduction of lipid peroxidation and at the same time, the free-radical scavenging activity of catalase, superoxide dismutase, and peroxidase were considerably enhanced [76]. Many studies had keenly explored the anti-inflammatory properties of pomegranate fruit [15, 77-79]. Studies indicated that pomegranate extract inhibited PMACI-induced proinflammatory cytokines assembly by inhibiting the gene expression. This is achieved by blocking JNK and ERKMAPK activation and NF- $\kappa$ B activation in human KU812 cells [80]. Larrosa et al. showed that pomegranate extract supplementations led to reduced prostaglandin E2 (PGE2) levels in the colon mucosa by downregulating the overexpressed COX-2 and prostaglandin E synthase (PTGES) levels owing to the action of ellagic acid [78]. Punica granatum extract had been found to be particularly effective for controlling oral inflammation, dental plaque, and bacterial and fungal counts in periodontal disease and Candida-associated denture stomatitis [81, 82]. Another study proposed that inhibition of number of signal transduction pathways and the downstream pathogenic cellular response by pomegranate extract or compounds may be a useful approach for the prevention of the onset and severity of inflammatory arthritis [77]. The dynamism of pomegranate fruit in newer areas of pharmacological effects might be delivered in the future.

\section{Pomegranate Extract as a Phytoestrogen}

Due to the possible adverse side effects of estrogenic stimulation (such as increase in tumor risk), many women have turned to phytoestrogens as an alternative for HRT [83]. The features that facilitate the chemicals to bind with ER are the steric and hydrophobic properties of a compound, as well as the hydrogen bonding between the phenolic hydroxyl group and the ER binding site [84]. Phytoestrogens bind to both forms of ER and showed a lower binding affinity than E2. Some of them exhibit a higher binding affinity to $\operatorname{ER} \beta$ than to $\mathrm{ER} \alpha$ which may indicate that they have different pathways for their actions and explains tissue specific changeability in phytoestrogenic action [85]. Both genomic and nongenomic mechanisms have been projected to explain phytoestrogenic effects on human health [86]. The best move towards the avoidance and handling of estrogen-dependent breast cancer is to selectively hold estrogen activity in the affected tissues without compromising its beneficial effects [87]. Regrettably, at this time, available antiestrogen such as tamoxifen used in the treatment of ER-positive breast cancer has side effects and agonism in the uterine endometrium, leading to an uncertain connection to endometrial carcinoma [88-90]. A competitive radioactive binding study was done to ascertain whether PME interacts with ER and had shown that PME binds to ER and inhibited the binding of labelled estrogen to ER in a dosedependent manner [53, 91].

\section{Pomegranate as a Potential Nutraceutical}

According to De Felice, who coined the term nutraceutical, it can be defined as, "a food (or part of a food) that provides medical or health benefits, including the prevention and/or treatment of a disease" [92]. It may range from isolated nutrients, herbal products, dietary supplements, and diets to genetically engineered "designer" foods and processed products such as cereals, soups, and beverages [93, 94]. Anthocyanidins (delphinidin, cyanidin, and pelargonidin) and hydrolysable tannins (such as punicalagin, pedunculagin, punicalin, gallagic, and ellagic acid esters of glucose), account for the major antioxidant activity of whole fruit $[22,95]$. The peel, which is also a major part of the fruit, is an imperative source of bioactive compounds such as phenolics, flavonoids, ellagitannins, proanthocyanidin compounds [96], minerals, [97], and complex polysaccharides [98]. Aviram and others reported that systolic blood pressure was reduced, after 1 year of pomegranate juice consumption. This was believed to be related to the potent antioxidant properties of pomegranate polyphenols [60]. Hong et al. confirmed that pomegranate juice and pomegranate extracts were more potent inhibitors of cell growth than isolated individual polyphenols in cell lines, influential synergistic and/or additive effects of several phytochemicals including proanthocyanidins, anthocyanins, and flavonoid glycosides [99]. Pomegranate contains agents, particularly polyphenolic flavonoids, which exert actions that could be well conducive to good oral health, particularly in relation to gingivitis development [100]. Pomegranate juice had the greatest antioxidant potency composite index among beverages like black cherry juice, cranberry juice, grape juice, apple juice, orange juice, red wines, blueberry juice, and iced tea; and the antioxidant activity was at least $20 \%$ superior to any of the other beverages tested [101-103]. Each and every part of pomegranate provides health benefits, that is, a nutraceutical food.

\section{Summary and Conclusions}

The discovery that plants generate hormonally active phytochemicals has altered our understanding of the connection 


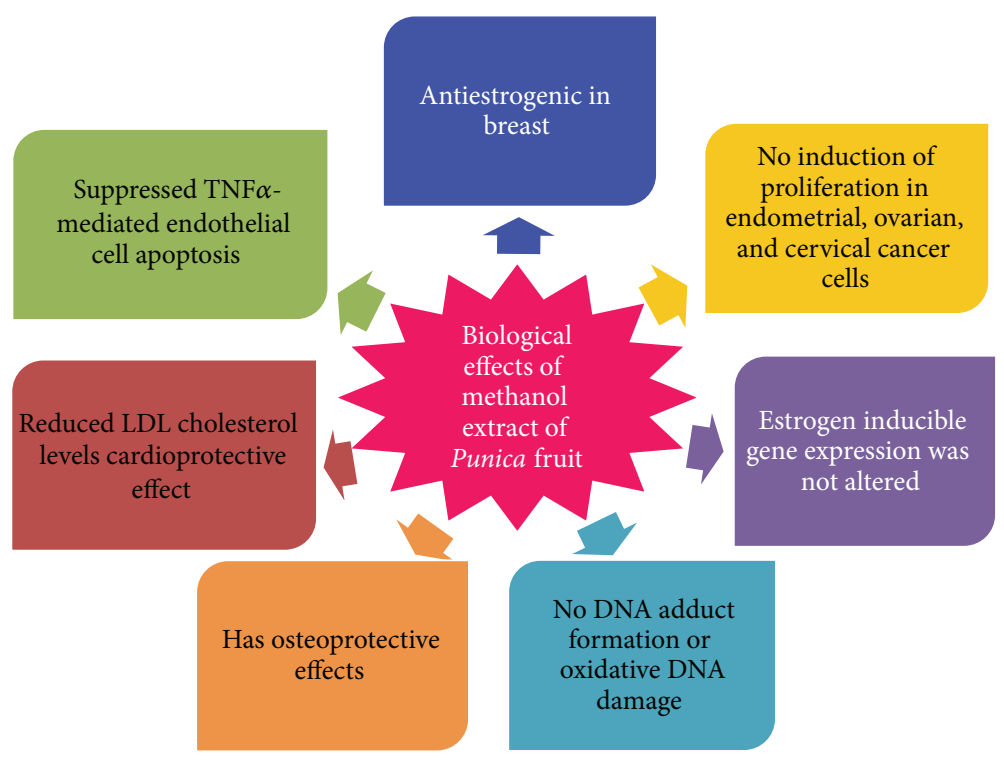

FIGURE 7: Biological effects of PME. PME was found to be antiestrogenic in breast, exhibited cardioprotective and osteoprotective effects, and had no estrogenicity in uterus. It did not induce DNA adduct formation or oxidative DNA damage and suppressed TNF $\alpha$-mediated endothelial cell apoptosis.

between diet and human health. It is well established that fruit or plant extracts are a complex mixture of various constituents and, in most of the instances, it is not clear whether a single compound or a mixture of compounds is responsible for the reported effects [104]. The thought of the whole herb or multiherb preparation not only addresses multiple targets, but possibly will alleviate the toxicity and side effects of a single, isolated compound from the plant. Many in vitro and in vivo studies pointed out high nutritional and potential tissue specific action of extract of Punica granatum. Proofs are accumulating that compounds present in a fruit or herb extract augment each other's biological effect. For example, it has been reported that quercetin and ellagic acid (both are also present in pomegranate) together make use of a more prominent inhibitory effect against cancer cell growth than either compound alone [105]. We had found that PME has antiestrogenic effect in the mammary gland, without compromising the beneficial effects of estrogen in the cardiovascular and skeletal system and had no estrogenicity in the uterus [53]. PME could possibly be considered as an ideal SERM and further studies might demonstrate its suitability and possible application in estrogen dependent breast cancers with beneficial effects in other hormone dependent tissues. Figure 7 describes the biological effects of PME, as observed in our studies. Furthermore, it would be valuable to investigate the long-term effects of PME in the in vivo models of estrogen deprivation to demonstrate its suitability in HRT. To achieve this goal, a better understanding is needed regarding the orchestrated action of SERM, receptor and coregulators that contribute to distinct patterns of gene expression. Although scientific research is being carried out to study the biological activity of a lot of food phytochemicals, the health claims attributed to the final marketed nutraceutical products have normally little or doubtful scientific foundation.
This is owing to the fact that a great deal of scientific conclusion is derived from animal testing and in vitro assays, while human clinical trials are limited. Some key issues such as metabolism, bioavailability, toxicity, and dose/response of these food bioactive compounds or nutraceuticals themselves have not been well recognized yet. Currently, numerous clinical trials are in progress exploring the therapeutic potential of pomegranate extracts. Its potential use as a nutraceutical needs to be investigated. We may thus anticipate that many of the open issues about the biological effect of extract of Punica granatum will be answered in the near future.

\section{Authors' Contribution}

Sreeja Sreekumar, Hima Sithul, Parvathy Muraleedharan, and Juberiya Mohammed Azeez have equal authorship.

\section{Conflict of Interests}

The authors declare that there is no conflict of interests regarding the publication of this paper.

\section{Acknowledgments}

The authors gratefully appreciate the support by grants from Kerala State Planning Board, Government of Kerala, India. Mrs. Sreeja Sreekumar was supported by Indian Council of Medical Research (ICMR), Government of India (Senior Research Fellowship), and Mrs. Parvathy Muraleedharan by Senior Research Fellowship from the Council of Scientific and Industrial Research, Government of India (CSIR award no. 09/716(0125)/2009-EMR-I). The views and opinions expressed in this paper are those of the authors. 


\section{References}

[1] M. G. Miguel, M. A. Neves, and M. D. Antunes, "Pomegranate (Punica granatum L.): a medicinal plant with myriad biological properties-a short review," Journal of Medicinal Plant Research, vol. 4, no. 25, pp. 2836-2847, 2010.

[2] M. I. Elghamry and I. M. Shihata, "Biological activity of phytoestrogens. 3. Experimental studies on some biological properties of beta-sitosterol," Planta Medica, vol. 14, no. 3, pp. 352-357, 1966.

[3] P. J. Magee and I. R. Rowland, "Phyto-oestrogens, their mechanism of action: current evidence for a role in breast and prostate cancer," The British Journal of Nutrition, vol. 91, no. 4, pp. 513531, 2004.

[4] S. Barnes, "Phytoestrogens and breast cancer," Bailliere's Clinical Endocrinology and Metabolism, vol. 12, no. 4, pp. 559-579, 1998.

[5] H. Adlercreutz, "Phyto-oestrogens and cancer," The Lancet Oncology, vol. 3, no. 6, pp. 364-373, 2002.

[6] M. G. Glazier and M. A. Bowman, "A review of the evidence for the use of phytoestrogens as a replacement for traditional estrogen replacement therapy," Archives of Internal Medicine, vol. 161, no. 9, pp. 1161-1172, 2001.

[7] A. Brzezinski and A. Debi, "Phytoestrogens: the "natural" selective estrogen receptor modulators?" European Journal of Obstetrics Gynecology and Reproductive Biology, vol. 85, no. 1, pp. 47-51, 1999.

[8] U. Halbreich and L. S. Kahn, "Selective oestrogen receptor modulators current and future brain and behaviour applications," Expert Opinion on Pharmacotherapy, vol. 1, no. 7, pp. 1385-1398, 2000.

[9] T. Hol, M. B. Cox, H. U. Bryant, and M. W. Draper, "Selective estrogen receptor modulators and postmenopausal women's health," Journal of Women's Health, vol. 6, no. 5, pp. 523-531, 1997.

[10] J. Sierens, J. A. Hartley, M. J. Campbell, A. J. C. Leathem, and J. V. Woodside, "Effect of phytoestrogen and antioxidant supplementation on oxidative DNA damage assessed using the comet assay," Mutation Research: DNA Repair, vol. 485, no. 2, pp. 169176, 2001.

[11] A. Fadavi, M. Barzegar, M. H. Azizi, and M. Bayat, "Physicochemical composition of ten pomegranate cultivars (Punica granatum L.) grown in Iran," Food Science and Technology International, vol. 11, no. 2, pp. 113-119, 2005.

[12] M. Viuda-Martos, J. Fernández-Lóaez, and J. A. Pérez-álvarez, "Pomegranate and its many functional components as related to human health: a review," Comprehensive Reviews in Food Science and Food Safety, vol. 9, no. 6, pp. 635-654, 2010.

[13] W. Elfalleh, H. Hannachi, N. Tlili, Y. Yahia, N. Nasri, and A. Ferchichi, "Total phenolic contents and antioxidant activities of pomegranate peel, seed, leaf and flower," Journal of Medicinal Plants Research, vol. 6, no. 32, pp. 4724-4730, 2012.

[14] H. Kohno, R. Suzuki, Y. Yasui, M. Hosokawa, K. Miyashita, and T. Tanaka, "Pomegranate seed oil rich in conjugated linolenic acid suppresses chemically induced colon carcinogenesis in rats," Cancer Science, vol. 95, no. 6, pp. 481-486, 2004.

[15] E. P. Lansky and R. A. Newman, "Punica granatum (pomegranate) and its potential for prevention and treatment of inflammation and cancer," Journal of Ethnopharmacology, vol. 109, no. 2, pp. 177-206, 2007.
[16] V. Monica, H. Raquel L Pinyi, and B. R. Josep, "Preventive and prophylactic mechanisms of action of pomegranate bioactive constituents," Evidence-Based Complementary and Alternative Medicine, vol. 2013, Article ID 789764, 18 pages, 2013.

[17] W. Elfalleh, N. Tlili, N. Nasri et al., "Antioxidant capacities of phenolic compounds and tocopherols from tunisian pomegranate (Punica granatum) fruits," Journal of Food Science, vol. 76, no. 5, pp. C707-C713, 2011.

[18] S. Jain, R. Rai, A. R. Upadhyaya, and G. Malhotra, "Punica granatum: a natural and recent approach towards dental problem," International Journal of Pharmaceutical Sciences and Research, vol. 2, no. 1, pp. 1-6, 2014.

[19] N. P. Seeram and M. G. Nair, "Inhibition of lipid peroxidation and structure-activity-related studies of the dietary constituents anthocyanins, anthocyanidins, and catechins," Journal of Agricultural and Food Chemistry, vol. 50, no. 19, pp. 5308-5312, 2002.

[20] Y. Amakura, M. Okada, S. Tsuji, and Y. Tonogai, "Determination of phenolic acids in fruit juices by isocratic column liquid chromatography," Journal of Chromatography A, vol. 891, no. 1, pp. 183-188, 2000.

[21] T. Tanaka, G.-I. Nonaka, and I. Nishioka, “Tannins and related compounds. XL. Revision of the structures of punicalin and punicalagin, and isolation and characterization of 2-Ogalloylpunicalin from the bark of Punica granatum L," Chemical and Pharmaceutical Bulletin, vol. 34, no. 2, pp. 650-655, 1986.

[22] M. I. Gil, F. A. Tomas-Barberan, B. Hess-Pierce, D. M. Holcroft, and A. A. Kader, "Antioxidant activity of pomegranate juice and its relationship with phenolic composition and processing," Journal of Agricultural and Food Chemistry, vol. 48, no. 10, pp. 4581-4589, 2000.

[23] H. Neuhofer, L. Witte, M. Gorunovic, and F.-C. Czygan, "Alkaloids in the bark of Punica granatum L. (Pomegranate) from Yugoslavia," Die Pharmazie, vol. 48, no. 5, pp. 389-391, 1993.

[24] A. Vidal, A. Fallarero, B. R. Peña et al., "Studies on the toxicity of Punica granatum L. (Punicaceae) whole fruit extracts," Journal of Ethnopharmacology, vol. 89, no. 2-3, pp. 295-300, 2003.

[25] D. A. van Elswijk, U. P. Schobel, E. P. Lansky, H. Irth, and J. van der Greef, "Rapid dereplication of estrogenic compounds in pomegranate (Punica granatum) using on-line biochemical detection coupled to mass spectrometry," Phytochemistry, vol. 65, no. 2, pp. 233-241, 2004.

[26] N. Artik, B. Ceremroglu, H. Murakami, and T. Mori, "Determination of phenolic compounds in pomegranate juice by using HPLC," Fruit Processing, vol. 8, pp. 492-499, 1998.

[27] S.-M. Cui, Y. Sasada, H. Sato, and N. Nii, "Cell structure and sugar and acid contents in the arils of developing pomegranate fruit," Journal of the Japanese Society for Horticultural Science, vol. 73, no. 3, pp. 241-243, 2004.

[28] E. Poyrazoğlu, V. Gökmen, and N. Artik, "Organic acids and phenolic compounds in pomegranates (Punica granatum L.) grown in Turkey," Journal of Food Composition and Analysis, vol. 15, no. 5, pp. 567-575, 2002.

[29] C. T. Du, P. L. Wang, and F. J. Francis, "Anthocyanins of Pomegranate, Punica granatum," Journal of Food Science, vol. 40, no. 2, pp. 417-418, 1975.

[30] S. Waheed, N. Siddique, A. Rahman, J. H. Zaidi, and S. Ahmad, "INAA for dietary assessment of essential and other trace elements in fourteen fruits harvested and consumed in Pakistan," Journal of Radioanalytical and Nuclear Chemistry, vol. 260, no. 3, pp. 523-531, 2004. 
[31] T. H. W. Huang, G. Peng, B. P. Kota et al., "Anti-diabetic action of Punica granatum flower extract: activation of PPAR- $\gamma$ and identification of an active component," Toxicology and Applied Pharmacology, vol. 207, no. 2, pp. 160-169, 2005.

[32] A. K. Batta and S. Rangaswami, "Crystalline chemical components of some vegetable drugs," Phytochemistry, vol. 12, no. 1, pp. 214-216, 1973.

[33] J. Lan, F. Lei, L. Hua, Y. Wang, D. Xing, and L. Du, "Transport behavior of ellagic acid of pomegranate leaf tannins and its correlation with total cholesterol alteration in HepG2 cells," Biomedical Chromatography, vol. 23, no. 5, pp. 531-536, 2009.

[34] R. H. Chaitra, M. Madhuri, T. Swaroop, D. Arijit, B. Sourav, and K. C. Rohit, "Evaluation of antimicrobial properties, phytochemical contents and antioxidant capacity of leaf extracts of Punica granatum L," Journal of Biological Sciences, vol. 1, pp. 3237, 2012.

[35] M. A. M. Nawwar, S. A. M. Hussein, and I. Merfort, "Leaf phenolics of Punica granatum," Phytochemistry, vol. 37, no. 4, pp. 1175-1177, 1994.

[36] R.-F. Wang, W.-D. Xie, Z. Zhang et al., "Bioactive compounds from the seeds of Punica granatum (pomegranate)," Journal of Natural Products, vol. 67, no. 12, pp. 2096-2098, 2004.

[37] S. Y. Schubert, E. P. Lansky, and I. Neeman, "Antioxidant and eicosanoid enzyme inhibition properties of pomegranate seed oil and fermented juice flavonoids," Journal of Ethnopharmacology, vol. 66, no. 1, pp. 11-17, 1999.

[38] E. Hornung, C. Pernstich, and I. Feussner, "Formation of conjugated $\Delta 11 \Delta 13$-double bonds by $\Delta 12$-linoleic acid $(1,4)$ acyl-lipid-desaturase in pomegranate seeds," European Journal of Biochemistry, vol. 269, no. 19, pp. 4852-4859, 2002.

[39] S. M. Abd El Wahab, N. M. El Fiki, S. F. Mostafa, and A. E. B. Hassan, "Characterization of certain steroid hormones in Punica granatum L. seeds," Bulletin of the Faculty of Pharmacy, vol. 36, pp. 11-15, 1998.

[40] N. D. Kim, R. Mehta, W. Yu et al., "Chemopreventive and adjuvant therapeutic potential of pomegranate (Punica granatum) for human breast cancer," Breast Cancer Research and Treatment, vol. 71, no. 3, pp. 203-217, 2002.

[41] E. P. Lansky, W. Jiang, H. Mo et al., "Possible synergistic prostate cancer suppression by anatomically discrete pomegranate fractions," Investigational New Drugs, vol. 23, no. 1, pp. 11-20, 2005.

[42] J. Jurenka, "Therapeutic applications of pomegranate (Punica granatum L.): a review," Alternative Medicine Review, vol. 13, no. 2, pp. 128-144, 2008.

[43] A. R. Neurath, N. Strick, Y.-Y. Li, and A. K. Debnath, "Punica granatum (Pomegranate) juice provides an HIV-1 entry inhibitor and candidate topical microbicide," BMC Infectious Diseases, vol. 4, article 41, 2004.

[44] M. Toi, H. Bando, C. Ramachandran et al., "Preliminary studies on the anti-angiogenic potential of pomegranate fractions in vitro and in vivo," Angiogenesis, vol. 6, no. 2, pp. 121-128, 2003.

[45] R. Mehta and E. P. Lansky, "Breast cancer chemopreventive properties of pomegranate (Punica granatum) fruit extracts in a mouse mammary organ culture," European Journal of Cancer Prevention, vol. 13, no. 4, pp. 345-348, 2004.

[46] M. A. L. Jeune, J. Kumi-Diaka, and J. Brown, "Anticancer activities of pomegranate extracts and genistein in human breast cancer cells," Journal of Medicinal Food, vol. 8, no. 4, pp. 469475, 2005.

[47] A. Faria and C. Conceição, "The bioactivity of pomegranate: impact on health and disease," Critical Reviews in Food Science and Nutrition, vol. 51, no. 7, pp. 626-634, 2011.
[48] L. Wang, A. Alcon, H. Yuan, J. Ho, Q.-J. Li, and M. MartinsGreen, "Cellular and molecular mechanisms of pomegranate juice-induced anti-metastatic effect on prostate cancer cells," Integrative Biology, vol. 3, no. 7, pp. 742-754, 2011.

[49] A. Burton, "Chemoprevention: eat ginger, rub on pomegranate," The Lancet Oncology, vol. 4, no. 12, p. 715, 2003.

[50] V. M. Adhami, I. A. Siddiqui, D. N. Syed, R. K. Lall, and H. Mukhtar, "Oral infusion of pomegranate fruit extract inhibits prostate carcinogenesis in the TRAMP model," Carcinogenesis, vol. 33, no. 3, pp. 644-651, 2012.

[51] L. Herszényi, I. Hritz, G. Lakatos, M. Z. Varga, and Z. Tulassay, "The behavior of matrix metalloproteinases and their inhibitors in colorectal cancer," International Journal of Molecular Sciences, vol. 13, no. 10, pp. 13240-13263, 2012.

[52] F. H. Sarkar, Y. Li, Z. Wang, and D. Kong, "Cellular signaling perturbation by natural products," Cellular Signalling, vol. 21, no. 11, pp. 1541-1547, 2009.

[53] S. Sreeja, T. R. Santhosh Kumar, B. S. Lakshmi, and S. Sreeja, "Pomegranate extract demonstrate a selective estrogen receptor modulator profile in human tumor cell lines and in vivo models of estrogen deprivation," The Journal of Nutritional Biochemistry, vol. 23, no. 7, pp. 725-732, 2012.

[54] N. Etique, I. Grillier-Vuissoz, and S. Flament, "Ethanol stimulates the secretion of matrix metalloproteinases 2 and 9 in MCF7 human breast cancer cells," Oncology Reports, vol. 15, no. 3, pp. 603-608, 2006.

[55] F. Afaq, A. Malik, D. Syed, D. Maes, M. S. Matsui, and H. Mukhtar, "Pomegranate fruit extract modulates UV-Bmediated phosphorylation of mitogen-activated protein kinases and activation of nuclear factor kappa B in normal human epidermal keratinocytes," Photochemistry and Photobiology, vol. 81, no. 1, pp. 38-45, 2005.

[56] L. S. Adams, N. P. Seeram, B. B. Aggarwal, Y. Takada, D. Sand, and D. Heber, "Pomegranate juice, total pomegranate ellagitannins, and punicalagin suppress inflammatory cell signaling in colon cancer cells," Journal of Agricultural and Food Chemistry, vol. 54, no. 3, pp. 980-985, 2006.

[57] S. Koyama, L. J. Cobb, H. H. Mehta et al., "Pomegranate extract induces apoptosis in human prostate cancer cells by modulation of the IGF-IGFBP axis," Growth Hormone and IGF Research, vol. 20, no. 1, pp. 55-62, 2010.

[58] B. Fuhrman, N. Volkova, and M. Aviram, "Pomegranate juice polyphenols increase recombinant paraoxonase-1 binding to high-density lipoprotein: studies in vitro and in diabetic patients," Nutrition, vol. 26, no. 4, pp. 359-366, 2010.

[59] F. de Nigris, S. Williams-Ignarro, L. O. Lerman et al., "Beneficial effects of pomegranate juice on oxidation-sensitive genes and endothelial nitric oxide synthase activity at sites of perturbed shear stress," Proceedings of the National Academy of Sciences of the United States of America, vol. 102, no. 13, pp. 4896-4901, 2005.

[60] M. Aviram, M. Rosenblat, D. Gaitini et al., "Pomegranate juice consumption for 3 years by patients with carotid artery stenosis reduces common carotid intima-media thickness, blood pressure and LDL oxidation," Clinical Nutrition, vol. 23, no. 3, pp. 423-433, 2004.

[61] K. M. Azadzoi, R. N. Schulman, M. Aviram, and M. B. Siroky, "Oxidative stress in arteriogenic erectile dysfunction: prophylactic role of antioxidants," The Journal of Urology, vol. 174, no. 1, pp. 386-393, 2005. 
[62] A. Esmaillzadeh, F. Tahbaz, I. Gaieni, H. Alavi-Majd, and L. Azadbakht, "Cholesterol-lowering effect of concentrated pomegranate juice consumption in type II diabetic patients with hyperlipidemia," International Journal for Vitamin and Nutrition Research, vol. 76, no. 3, pp. 147-151, 2006.

[63] M. Aviram, N. Volkova, R. Coleman et al., "Pomegranate phenolics from the peels, arils, and flowers are antiatherogenic: studies in vivo in atherosclerotic apolipoprotein E-deficient $\left(\mathrm{E}^{\circ}\right)$ mice and in vitro in cultured macrophages and lipoproteins," Journal of Agricultural and Food Chemistry, vol. 56, no. 3, pp. 1148-1157, 2008.

[64] V. C. Jordan, E. Phelps, and J. U. Lindgren, "Effects of antiestrogens on bone in castrated and intact female rats," Breast Cancer Research and Treatment, vol. 10, no. 1, pp. 31-35, 1987.

[65] H. Z. Ke, V. M. Paralkak, W. A. Grasser et al., "Effects of CP336,156, a new, nonsteroidal estrogen agonist/antagonist, on bone, serum cholesterol, uterus, and body composition in rat models," Endocrinology, vol. 139, no. 4, pp. 2068-2076, 1998.

[66] L. J. Lerner and V. C. Jordan, "Development of antiestrogens and their use in breast cancer: eighth cain memorial award lecture," Cancer Research, vol. 50, no. 14, pp. 4177-4189, 1990.

[67] J. Banu, "The ovariectomized mice and rats," Osteoporosis Research, SpringerLondon, 2011.

[68] S. Sreekumar, Selective estrogen receptor modulator (SERM) activity of Pomegranate (Punica granatum L.): implications for estrogen dependant breast cancer [dissertation], University of Kerala, 2011.

[69] Y.-Y. Kim, S.-H. Kim, S. Oh et al., "Increased fat due to estrogen deficiency induces bone loss by elevating monocyte chemoattractant protein-1 (MCP-1) production," Molecules and Cells, vol. 29, no. 3, pp. 277-282, 2010.

[70] T. S. R. Neerup, M. Stahlhut, J. S. Petersen et al., "ZP2307, a novel, cyclic PTH(1-17) analog that augments bone mass in ovariectomized rats," Bone, vol. 48, no. 6, pp. 1319-1327, 2011.

[71] H. Wang, S. Tranguch, H. Xie, G. Hanley, S. K. Das, and S. K. Dey, "Variation in commercial rodent diets induces disparate molecular and physiological changes in the mouse uterus," Proceedings of the National Academy of Sciences of the United States of America, vol. 102, no. 28, pp. 9960-9965, 2005.

[72] A. A. Amini and L. S. Nair, "Lactoferrin: a biologically active molecule for bone regeneration," Current Medicinal Chemistry, vol. 18, no. 8, pp. 1220-1229, 2011.

[73] L. J. Ignarro, R. E. Byrns, D. Sumi, F. de Nigris, and C. Napoli, "Pomegranate juice protects nitric oxide against oxidative destruction and enhances the biological actions of nitric oxide," Nitric Oxide: Biology and Chemistry, vol. 15, no. 2, pp. 93-102, 2006.

[74] H. S. Parmar and A. Kar, "Medicinal values of fruit peels from Citrus sinensis, Punica granatum, and Musa paradisiaca with respect to alterations in tissue lipid peroxidation and serum concentration of glucose, insulin, and thyroid hormones," Journal of Medicinal Food, vol. 11, no. 2, pp. 376-381, 2008.

[75] H. Z. Toklu, M. U. Dumlu, Ö. Sehirli et al., "Pomegranate peel extract prevents liver fibrosis in biliary-obstructed rats," Journal of Pharmacy and Pharmacology, vol. 59, no. 9, pp. 1287-1295, 2007.

[76] M. K. N. Chidambara Murthy, G. K. Jayaprakasha, and R. P. Singh, "Studies on antioxidant activity of pomegranate (Punica granatum) peel extract using in vivo models," Journal of Agricultural and Food Chemistry, vol. 50, no. 17, pp. 4791-4795, 2002.
[77] M. Shukla, K. Gupta, Z. Rasheed, K. A. Khan, and T. M. Haqqi, "Consumption of hydrolyzable tannins-rich pomegranate extract suppresses inflammation and joint damage in rheumatoid arthritis," Nutrition, vol. 24, no. 7-8, pp. 733743, 2008.

[78] M. Larrosa, A. González-Sarrías, M. J. Yáñez-Gascón et al., "Anti-inflammatory properties of a pomegranate extract and its metabolite urolithin-A in a colitis rat model and the effect of colon inflammation on phenolic metabolism," The Journal of Nutritional Biochemistry, vol. 21, no. 8, pp. 717-725, 2010.

[79] C.-J. Lee, L.-G. Chen, W.-L. Liang, and C.-C. Wang, "Antiinflammatory effects of Punica granatum Linne in vitro and in vivo," Food Chemistry, vol. 118, no. 2, pp. 315-322, 2010.

[80] Z. Rasheed, N. Akhtar, A. N. Anbazhagan, S. Ramamurthy, M. Shukla, and T. M. Haqqi, "Polyphenol-rich pomegranate fruit extract (POMx) suppresses PMACI-induced expression of pro-inflammatory cytokines by inhibiting the activation of MAP kinases and NF- $\kappa$ B in human KU812 cells," Journal of Inflammation, vol. 6, article 1, 2009.

[81] S. M. S. Menezes, L. N. Cordeiro, and G. S. B. Viana, "Punica granatum (pomegranate) extract is active against dental plaque," Journal of Herbal Pharmacotherapy, vol. 6, no. 2, pp. 79-92, 2006.

[82] L. C. de Souza Vasconcelos, M. C. Correia Sampaio, F. Correia Sampaio, and J. S. Higino, "Use of Punica granatum as an antifungal agent against candidosis associated with denture stomatitis," Mycoses, vol. 46, no. 5-6, pp. 192-196, 2003.

[83] A. A. A. Ewies, "Phytoestrogens in the management of the menopause: up-to-date," Obstetrical and Gynecological Survey, vol. 57, no. 5, pp. 306-313, 2002.

[84] J.-Y. Hu and T. Aizawa, "Quantitative structure-activity relationships for estrogen receptor binding affinity of phenolic chemicals," Water Research, vol. 37, no. 6, pp. 1213-1222, 2003.

[85] K. D. R. Setchell, "Phytoestrogens: the biochemistry, physiology, and implications for human health of soy isoflavones," American Journal of Clinical Nutrition, vol. 68, no. 6, pp. 1333S-1346S, 1998.

[86] J. J. B. Anderson, M. Anthony, M. Messina, and S. C. Garner, "Effects of phyto-oestrogens on tissues," Nutrition Research Reviews, vol. 12, no. 1, pp. 75-116, 1999.

[87] Y. Shang and M. Brown, "Molecular determinants for the tissue specificity of SERMs," Science, vol. 295, no. 5564, pp. 2465-2468, 2002.

[88] K. Yao and V. C. Jordan, "Questions about tamoxifen and the future use of antiestrogens," Oncologist, vol. 3, no. 2, pp. 104$110,1998$.

[89] B. Fisher, J. Dignam, J. Bryant et al., "Five versus more than five years of tamoxifen therapy for breast cancer patients with negative lymph nodes and estrogen receptor-positive tumors," Journal of the National Cancer Institute, vol. 88, no. 21, pp. 15291542, 1996.

[90] L. Cortesi, E. de Matteis, I. Rashid et al., "Distribution of second primary malignancies suggests a bidirectional effect between breast and endometrial cancer a population-based study," International Journal of Gynecological Cancer, vol. 19, no. 8, pp. 1358-1363, 2009.

[91] I. Maru, J. Ohnishi, S. Yamaguchi, Y. Oda, K. Kakehi, and Y. Ohta, "An estrogen-like activity in pomegranate juice," Journal of the Japanese Society For Food Science and Technology, vol. 48, no. 2, pp. 146-149, 2001. 
[92] V. Brower, "Nutraceuticals: poised for a healthy slice of the healthcare market?" Nature Biotechnology, vol. 16, no. 8, pp. 728-730, 1998.

[93] A. Malik, "The potentials of nutraceuticals," Pharmainfo.net, vol. 6, 2008.

[94] H. Dureja, D. Kaushik, and V. Kumar, "Developments in nutraceuticals," Indian Journal of Pharmacology, vol. 35, no. 6, pp. 363-372, 2003.

[95] F. Tezcan, M. Gültekin-Özgüven, T. Diken, B. Özçelik, and F. B. Erim, "Antioxidant activity and total phenolic, organic acid and sugar content in commercial pomegranate juices," Food Chemistry, vol. 115, no. 3, pp. 873-877, 2009.

[96] Y. Li, C. Guo, J. Yang, J. Wei, J. Xu, and S. Cheng, "Evaluation of antioxidant properties of pomegranate peel extract in comparison with pomegranate pulp extract," Food Chemistry, vol. 96, no. 2, pp. 254-260, 2006.

[97] S. H. Mirdehghan and M. Rahemi, "Seasonal changes of mineral nutrients and phenolics in pomegranate (Punica granatum L.) fruit," Scientia Horticulturae, vol. 111, no. 2, pp. 120-127, 2007.

[98] M. Jahfar, K. K. Vijayan, and P. Azadi, "Studies on a polysaccharide from the fruit rind of Punica granatum," Research Journal of Chemistry and Environment, vol. 7, no. 1, pp. 43-50, 2003.

[99] M. Y. Hong, N. P. Seeram, and D. Heber, "Pomegranate polyphenols down-regulate expression of androgen-synthesizing genes in human prostate cancer cells overexpressing the androgen receptor," The Journal of Nutritional Biochemistry, vol. 19, no. 12, pp. 848-855, 2008.

[100] R. A. DiSilvestro, D. J. DiSilvestro, and D. J. DiSilvestro, "Pomegranate extract mouth rinsing effects on saliva measures relevant to gingivitis risk," Phytotherapy Research, vol. 23, no. 8, pp. 1123-1127, 2009.

[101] N. P. Seeram, M. Aviram, Y. Zhang et al., "Comparison of antioxidant potency of commonly consumed polyphenol-rich beverages in the United States," Journal of Agricultural and Food Chemistry, vol. 56, no. 4, pp. 1415-1422, 2008.

[102] N. S. Kelawala and L. Ananthanarayan, "Antioxidant activity of selected foodstuffs," International Journal of Food Sciences and Nutrition, vol. 55, no. 6, pp. 511-516, 2004.

[103] A. Schäfer, Z. Chovanová, J. Muchová et al., "Inhibition of COX1 and COX-2 activity by plasma of human volunteers after ingestion of French maritime pine bark extract (Pycnogenol)," Biomedicine and Pharmacotherapy, vol. 60, no. 1, pp. 5-9, 2006.

[104] N. P. Seeram, L. S. Adams, S. M. Henning et al., "In vitro antiproliferative, apoptotic and antioxidant activities of punicalagin, ellagic acid and a total pomegranate tannin extract are enhanced in combination with other polyphenols as found in pomegranate juice," The Journal of Nutritional Biochemistry, vol. 16, no. 6, pp. 360-367, 2005.

[105] S. Meenakshi, G. Kalpana, A. K. Khursheed, and M. H. Tariq, "Bioavailable constituents/metabolites of pomegranate (Punica granatum L) preferentially inhibit COX2 activity ex vivo and IL-1beta-induced PGE2 production in human chondrocytes in vitro," Journal of Inflammation, vol. 13, no. 5, p. 9, 2008. 

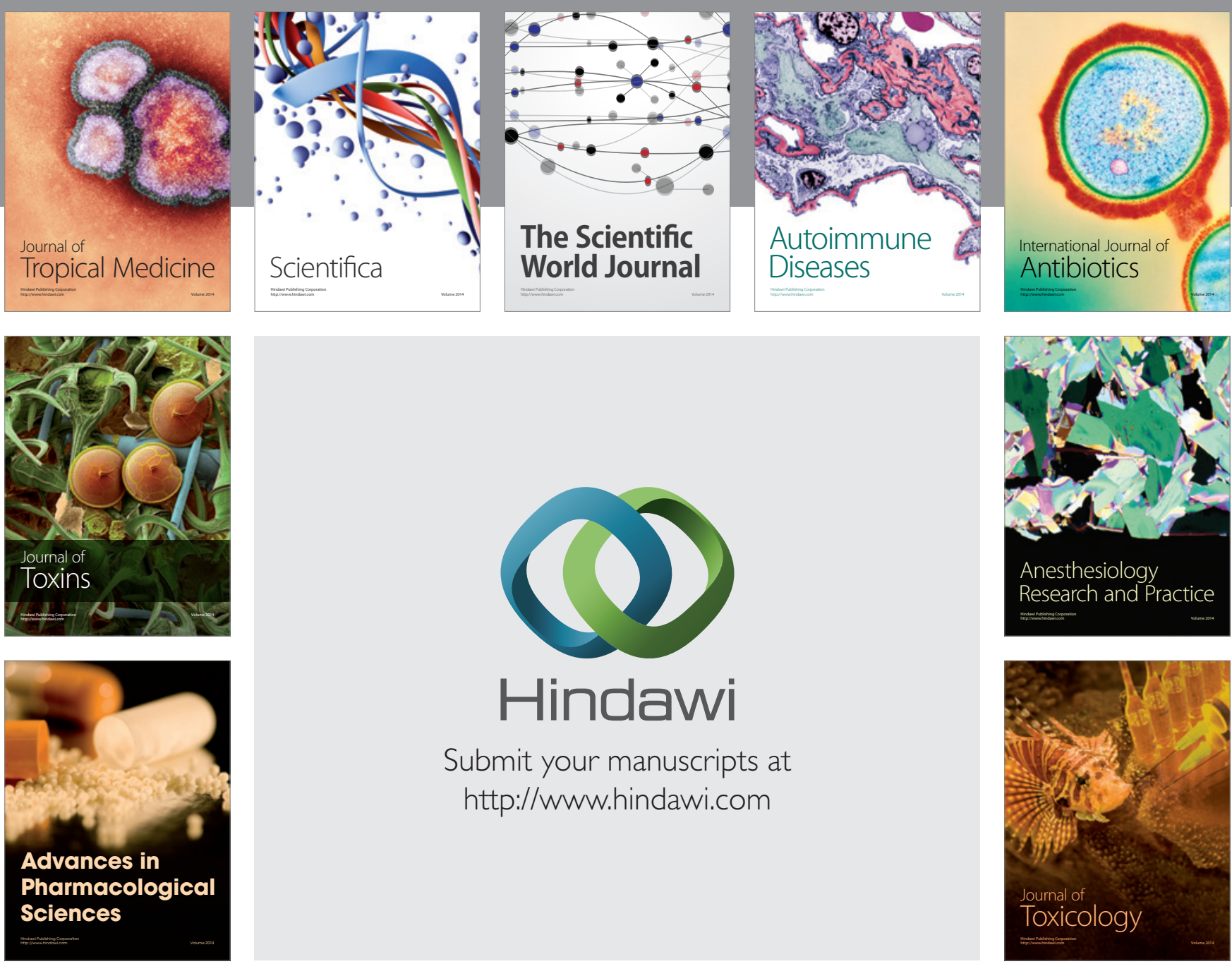

\section{Hindawi}

Submit your manuscripts at

http://www.hindawi.com
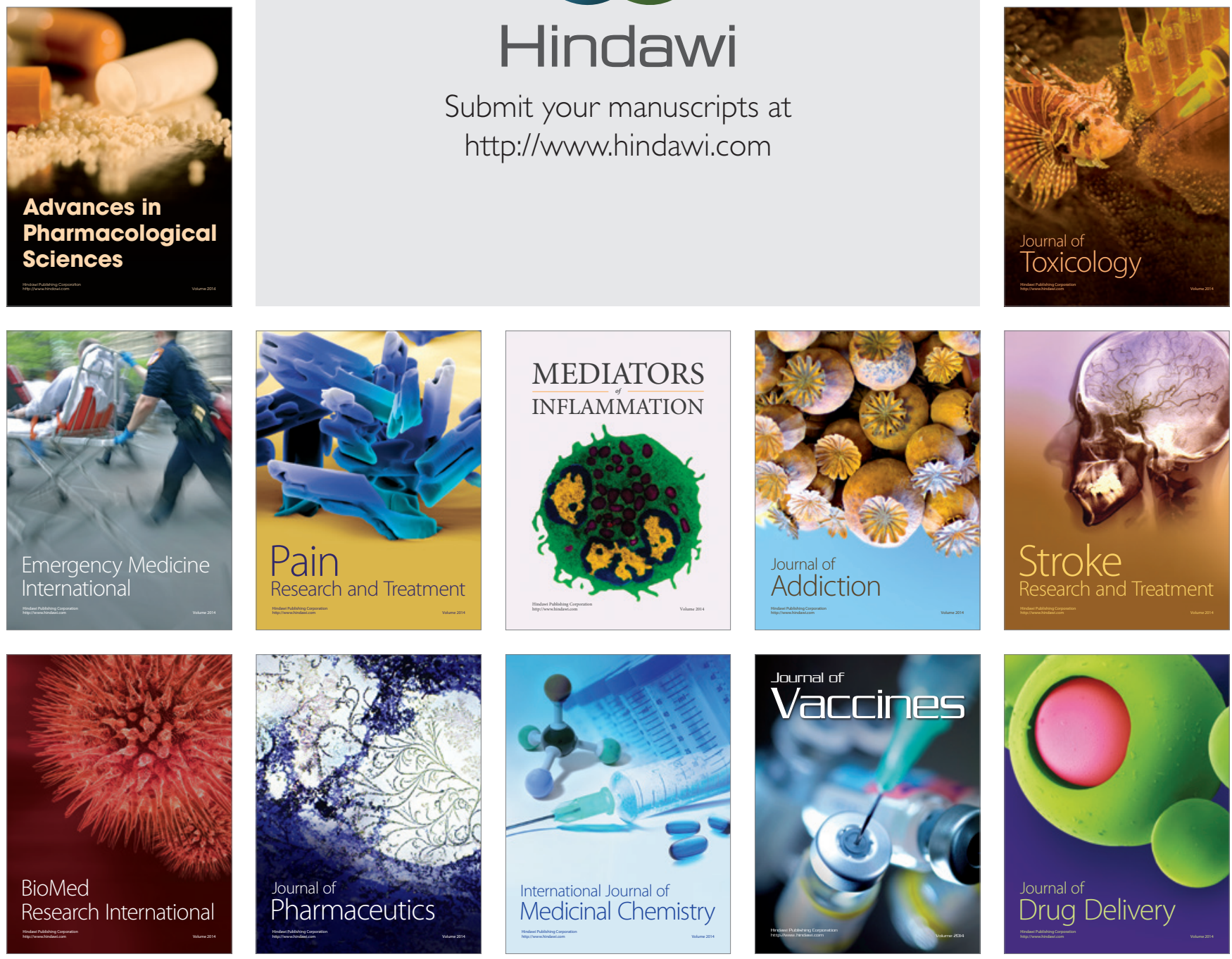